\title{
C-type natriuretic peptide plasma levels are reduced in obese adolescents
}

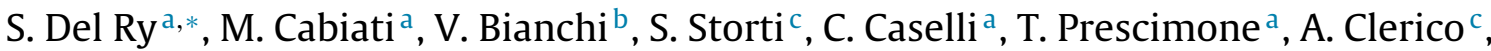 \\ G. Saggese ${ }^{\text {b }}$, D. Giannessi ${ }^{\text {a }}$, G. Federico ${ }^{\text {b }}$ \\ a CNR Institute of Clinical Physiology, CNR, Italy \\ b Sezione di Diabetologia Pediatrica, U.O. Pediatria Universitaria, Azienda Ospedaliero Universitaria Pisana, Pisa, Italy \\ ${ }^{c}$ Fondazione G. Monasterio, Pisa, Italy
}

\section{A R T I C L E I N F O}

\section{Article history:}

Received 22 July 2013

Received in revised form

24 September 2013

Accepted 24 September 2013

Available online 8 October 2013

\section{Keywords:}

C-type natriuretic peptide

Obesity

Adolescents

Natriuretic peptides

\begin{abstract}
A B S T R A C T
The high prevalence of obesity in children may increase the magnitude of lifetime risk of cardiovascular disease (CD). At present, explicit data for recommending biomarkers as routine pre-clinical markers of CD in children are lacking. C-type natriuretic peptide (CNP) is assuming increasing importance in CD; in adults with heart failure, its plasma levels are related to clinical and functional disease severity. We have previously reported five different reference intervals for blood CNP as a function of age in healthy children; however, data on plasma CNP levels in obese children are still lacking. Aim of this study was to assess CNP levels in obese adolescents and verify whether they differ from healthy subjects. Plasma CNP was measured in 29 obese adolescents (age: $11.8 \pm 0.4$ years; BMI: $29.8 \pm 0.82$ ) by radioimmunoassay and compared with the reference values of healthy subjects. BNP was also measured. Both plasma CNP and BNP levels were significantly lower in the obese adolescents compared to the appropriate reference values (CNP: $3.4 \pm 0.2$ vs $13.6 \pm 2.3 \mathrm{pg} / \mathrm{ml}, p<0.0001$; BNP: $18.8 \pm 2.6$ vs $36.9 \pm 5.5 \mathrm{pg} / \mathrm{ml}, p=0.003$ ). There was no significant difference between CNP values in males and females. As reported in adults, we observed lower plasma CNP and BNP levels in obese children, suggesting a defective natriuretic peptide system in these patients. An altered regulation of production, clearance and function of natriuretic peptides, already operating in obese adolescents, may possibly contribute to the future development of CD. Thus, the availability of drugs promoting the action of natriuretic peptides may represent an attractive therapeutic option to prevent CD.
\end{abstract}

(c) 2013 Elsevier Inc. All rights reserved.

\section{Introduction}

Obesity is the result of a chronic caloric imbalance, when more calories are assumed than consumed each day. Most obese adults were obese as adolescents and most adolescents were overweight and/or obese as children [40]; in fact, the origins of obesity are being traced to early childhood development. Childhood obesity is a worldwide health problem and its prevalence is increasing steadily and dramatically worldwide [44]. Obese children have a much greater likelihood than their normal-weight counterparts of acquiring dyslipidemia, hypertension and impaired glucose metabolism, with an increased risk of developing cardiovascular and metabolic diseases as adults [33]. Childhood obesity is also a major risk for early onset of endothelial dysfunction and atherosclerosis [30,48]. At present, explicit data for recommending biomarkers as routine

\footnotetext{
* Corresponding author at: CNR Institute of Clinical Physiology, Via Giuseppe Moruzzi 1, 56124 Pisa, Italy. Tel.: +39 050 3152793; fax: +39 0503152166.

E-mail address: delry@ifc.cnr.it (S. Del Ry).
}

pre-clinical indices of cardiovascular disease $(C D)$ in children are lacking. C-type natriuretic peptide (CNP), a member of natriuretic cardiac peptides, is assuming increasing importance in cardiovascular disease. In adults a relationship between plasma CNP levels and clinical and functional disease severity was observed, especially in heart failure [10-15,20,22,35,46,49]. Recently, five different reference intervals for blood CNP, as a function of age, were reported in healthy children [16]. In addition, it has been shown that natriuretic peptides play a central role in the regulation of body weight and energy metabolism [32]. Interestingly, it has been shown that ANP and BNP are significantly lower in overweight and obese adult subjects than in the lean ones $[8,18,21]$, probably contributing to insulin resistance and hypertension. Data on natriuretic peptides in children of pediatric age are scarce and limited to CNP in infancy [36-38], while data on plasma CNP levels in obese children are still lacking.

Aims of the present study were to assess how plasma CNP levels behave in obese adolescents compared to normal weight subjects, and whether they show the same pattern observed for BNP and ANP in adult obese patients. To better describe the 
Table 1

Clinical characteristics of the studied subjects.

\begin{tabular}{ll}
\hline Morphometric features (cases, $n=29)$ & \\
\hline Sex & $17 \sigma^{7}-12$ \\
Age (years) & $11.77 \pm 0.4$ \\
Pubertal stage & $1: n=7$ \\
& $2: n=12$ \\
& $3: n=5$ \\
& $4: n=4$ \\
Height (cm) & $5: n=1$ \\
Weight (kg) & $154.43 \pm 2.2$ \\
BMI & $71.75 \pm 2.9$ \\
Obese/overweight & $29.8 \pm 0.8$ \\
& Obese, $n=25$ \\
Fat mass, FM (\%) & Overweight, $n=4$ \\
Fat mass, FM (percentile) & $37.1 \pm 1.2$ \\
& $>95, n=8$ \\
Systolic pressure, SBP (mmHg) & $>98, n=21$ \\
Systolic pressure, SBP (percentile) & $109 \pm 2$ \\
Diastolic pressure, DBP (mmHg) & $55.25 \pm 4.9$ \\
Diastolic pressure, DBP (percentile) & $65 \pm 1$ \\
\hline
\end{tabular}

neuroendocrine profile, BNP was also measured in the same samples.

\section{Methods}

\subsection{Subjects and plasma collection}

Twenty-nine overweight/obese adolescents $(17 \mathrm{M}, 12 \mathrm{~F}$, age $11.8 \pm 0.4$ years), without cardiac dysfunction, referred as outpatients to the Unit of Pediatric Endocrinology and Diabetes, Department of Pediatrics, University of Pisa, Italy, were enrolled in the study.

Table 1 summarizes the clinical details of each participant in the study. BMI, calculated using the formula weight $(\mathrm{kg}) /$ height $(\mathrm{m})^{2}$, was $29.8 \pm 0.82$, corresponding to $2.9 \pm 0.7 Z$-scores [6]. According to the definition of the international Task Force on Obesity in childhood and using population reference data specific for age and sex for BMI [7], 25/29 were obese while the remaining 4 were overweight. Total body fat, measured using the Tanita BC-418 Segmental Body Composition Analyser (Tanita Corporation, Tokyo, Japan) showed that our patients had FM\% in the range of obesity [27].

Blood pressure was measured by the same investigator using a standard validated protocol. In two subjects systolic blood pressure was above the 95th percentile for height, age, and sex-specific reference values [45] indicating a condition of systolic hypertension.

Table 2 summarizes the laboratory characteristics of each participant in the study. Fasting plasma glucose (FPG) was normal in all. Fifteen subjects showed HOMA-IR (HOmeostasis Model Assessment of Insulin Resistance) values $>2.0$ Z-scores, suggesting that they had a reduced insulin sensitivity. This index was calculated according the formula: fasting plasma insulin in $\mathrm{uU} / \mathrm{ml} \times \mathrm{FPG}$ in $\mathrm{mmol} / \mathrm{L} / 22.5$ [26]. The results were compared with reference values specific for Italian children and adolescents, obtained using the same formula [9].

Regarding blood lipids, according to reference values specific for age and sex [43], four patients had levels of total cholesterol above the 95th percentile; four had LDL cholesterol above the 95th percentile, while tryglycerides were increased in six. Blood levels of HDL cholesterol were lower than 5 th percentile in four patients [43].

Blood samples were collected in all the subjects by venipuncture, in the morning after an overnight fasting. In order to minimize degradation, blood samples for CNP were collected in icechilled disposable polypropylene tubes containing EDTA $(1 \mathrm{mg} / \mathrm{ml})$
Table 2

Laboratory findings of the studied subjects.

\begin{tabular}{|c|c|c|}
\hline $\begin{array}{l}\text { Biochemical } \\
\text { parameters }\end{array}$ & Case $(n=29)$ & Reference cut-off \\
\hline Glycemia (mg/dl) & $72.5 \pm 1.9$ & $<100 \mathrm{mg} / \mathrm{dl}$ \\
\hline Insulin (uU/ml) & $21.3 \pm 2.2$ & $<15 \mathrm{uUI} / \mathrm{ml}$ \\
\hline HOMA-IR & $4.0 \pm 0.4$ & $\begin{array}{l}\text { Males: } 1.37 \pm 0.7 \\
\text { Females: } 1.65 \pm 1.1\end{array}$ \\
\hline HOMA-IR (Z-score) & $2.9 \pm 0.5$ & - \\
\hline Cholesterol (mg/dl) & $172 \pm 7$ & $\begin{array}{l}<180 \mathrm{mg} / \mathrm{dl}(<75 \text { th percentile }) \\
\text { acceptable } \\
>210 \mathrm{mg} / \mathrm{dl}(>95 \text { th percentile }) \\
\text { elevated }\end{array}$ \\
\hline $\mathrm{HDL}(\mathrm{mg} / \mathrm{dl})$ & $45 \pm 2$ & $>37 \mathrm{mg} / \mathrm{dl}$ (>5th percentile) \\
\hline $\mathrm{LDL}(\mathrm{mg} / \mathrm{dl})$ & $107 \pm 5$ & $\begin{array}{l}<110 \mathrm{mg} / \mathrm{dl}(<75 \text { th percentile) } \\
\text { acceptable } \\
>135 \mathrm{mg} / \mathrm{dl}(>95 \text { th percentile }) \\
\text { elevated }\end{array}$ \\
\hline Triglycerides (mg/dl) & $97 \pm 10$ & $\begin{array}{l}<110 \mathrm{mg} / \mathrm{dl} \text { ( }<75 \text { th percentile) } \\
\text { acceptable } \\
>170 \mathrm{mg} / \mathrm{dl} \text { in females }(>95 \mathrm{th} \\
\text { percentile) elevated } \\
>150 \mathrm{mg} / \mathrm{dl} \text { in males }(>95 \mathrm{th} \\
\text { percentile) elevated }\end{array}$ \\
\hline
\end{tabular}

and aprotinin $(500 \mathrm{KIU} / \mathrm{ml})$ to prevent proteolysis. Samples were rapidly separated by centrifugation for $15 \mathrm{~min}$ at $4{ }^{\circ} \mathrm{C}$, and plasma stored frozen at $-80^{\circ} \mathrm{C}$ in $1-\mathrm{ml}$ aliquots in polypropylene tubes until assay, performed within 1 month. Blood samples for blood glucose and lipids assays were collected in lithium-heparin containing vials, while insulin in EDTA containing vials.

The study was conducted in accordance with the guidelines proposed in the Helsinki Declaration and approved by the local ethics committee. Informed consent was obtained from the parents of each subject.

\subsection{Biochemical parameters assays}

A Cobas Integra 400 analyser (Roche, Italy) and the appropriate commercial kits were used to measure blood glucose (Cobas Integra 400 Glucose HK; enzymatic reference method with hexokinase), total cholesterol (Cobas Integra 400 Cholesterol; enzymatic, colorimetric method with cholesterol esterase, cholesterol oxidase, and 4-aminoantipyrine), HDL and LDL cholesterol fractions (Cobas Integra 400 HDL-Cholesterol and LDL-Cholesterol plus 2nd generation; homogeneous enzymatic colorimetric assays) and tryglicerides (Cobas Integra 400 Tryglicerides; enzymatic, colorimetric method with glycerol phosphate oxidase and 4-aminophenazone).

Circulating insulin levels were measured by a commercial immunoassay kit (Access ${ }^{\circledR}$ Ultrasensitive Insulin, Beckman Coulter Inc., Fullerton, CA, USA), with a sensitivity of $0.03 \mu \mathrm{IU} / \mathrm{mL}$ and a precision of $<10 \% \mathrm{CV}$.

\subsection{CNP, BNP assay}

CNP was directly measured in plasma by a specific radioimmunoassay (RIA) (Phoenix Pharmaceuticals, Belmont, CA, USA). Each sample was determined in duplicate and the assay was carried out on ice. A control sample, prepared by using known amounts of $\mathrm{CNP}$ added to the assay buffer and stored in aliquots to $-80^{\circ} \mathrm{C}$, was assayed in each run for quality control.

As reported in a previous study of ours [16], the working range was derived by the mean dose-response curve for CNP assay and the mean imprecision profile, calculated by a previously described computer program [34]; at the low range (CNP concentration: $5-80 \mathrm{pg} /$ tube) the CV\% resulted lower than $20 \%$ CNP in vitro-stability was evaluated measuring a plasma pool in different experiments performed during 12 months and the between-assay 
Table 3

Reference intervals for CNP and BNP plasma levels in childhood (modified by Ref. [16]).

\begin{tabular}{lcc}
\hline Age reference intervals & $\mathrm{CNP}(\mathrm{pg} / \mathrm{ml})$ & $\mathrm{BNP}(\mathrm{pg} / \mathrm{ml})$ \\
\hline 0-3 days & $11.6 \pm 2.1$ & $396.2 \pm 100.3$ \\
4-30 days & $16.4 \pm 3.7$ & $99.6 \pm 36.3$ \\
1-12 months & $15.4 \pm 2.7$ & $29.2 \pm 3.92$ \\
1-12 years & $13.6 \pm 2.3$ & $37.2 \pm 5.7$ \\
\hline
\end{tabular}

variability resulted $<30 \%(n=7)$. Within-assay variability was evaluated using pools with different CNP concentration and both resulted $<20 \%: 7.05 \pm 0.2 \mathrm{pg} /$ tube $(n=9$ duplicate assays, $C V=11 \%$ ) and $12.4 \pm 1.1 \mathrm{pg} /$ tube $(n=5$ duplicate assays, $C V=18 \%) \mathrm{pg} /$ tube. Analytical sensitivity resulted $0.77 \pm 0.05 \mathrm{pg} /$ tube.

Plasma BNP was measured using the fully automated Access platform (Triage BNP reagents, Access Immunoassay Systems, REF 98200; Beckman Coulter Inc., Fullerton, CA, USA). The analytical characteristics and performance of the Access immunoassay method used in this study for measurement of BNP were previously evaluated [5] as well as the reference ranges in childhood [39].

Plasma CNP and BNP results were compared with appropriate reference values specific for age and sex [16]. In Table 3 the reference intervals for CNP and BNP plasma levels in childhood, obtained in a previous study of ours [16], were reported.

\subsection{Statistical analysis}

All sample values and other data for quality control of the RIA system were calculated using a previously described computer program [34]; the interpolation of the dose-response curves was computed using a four-parameter logistic function [34]. Because plasma CNP values are not normally distributed, natural logarithmic transformation of data was used for statistical analysis when needed. Differences of CNP levels between two independent groups were assessed by unpaired $t$-test. Relations between variables were assessed by linear regression. Results are expressed as mean \pm SEM and a $p$-value $<0.05$ was considered significant.

\section{Results}

Plasma CNP resulted significantly lower $(p<0.0001)$ in the obese subjects in comparison with the appropriate reference values (Fig. 1a) [16]. BNP plasma levels were also compared with the appropriate reference values previously determined in healthy children $(37.2 \pm 5.7 \mathrm{pg} / \mathrm{ml})$ [16] and showed significantly lower levels $(p=0.003)$ in obese children with respect to controls, mimicking the trend already observed in obese adults (Fig. 1b). When the results were analyzed as a function of gender, no significant difference for CNP values was found between males and females. A significant positive correlation between BNP and glycemia $(r=0.33$; $p<0.05$ ) was observed.

Considering the biochemical parameters analyzed in obese children (glycemia, insulin, cholesterol, HDL, LDL and triglycerides) the only significant correlations resulted between CNP and HDL $(r=0.37, p=0.048)$ as well as between BNP and HDL $(r=0.4$, $p=0.029)$ and triglycerides $(r=0.5, p=0.005)$ confirming their role in lipolysis and adipogenesis [3,32].

No significant correlation were observed between CNP or BNP and the morphometric features.

\section{Discussion}

This study reports for the first time the behavior of CNP plasma levels in obese adolescents, showing that overweight and obese children have significantly lower levels than normal-weight subjects. BNP plasma levels measured in the same subjects also resulted lower, confirming reports from previous investigators in obese adults $[21,28,29,32,47]$ and suggesting a defective natriuretic peptide system in these patients.

There are several mechanisms that could be potentially responsible for the inverse association between natriuretic peptide plasma levels and body mass index [2,24]. One of these may be an increased expression of the natriuretic peptide clearance receptors (NPR-C) on adipocyte cells and/or impaired synthesis/release of natriuretic peptides from myocytes found in obese subjects [1]. Another mechanism for the reduced secretion of natriuretic peptides might be an impaired myocardial hormone release [23] or synthesis [31] as a consequence of overweight/obesity. Recently, we observed lower levels of BNP, ANP and CNP mRNA expression in cardiac tissue of obese rats in comparison with their normal-weight counterparts, suggesting that obesity may be associated with a decreased synthesis of these peptides by cardiac cells [3]. Thus, we hypothesize that a similar obesity-induced mechanism might also be operating in obese humans, including children and adolescents.

Thus, in our overweight/obese adolescents a decreased synthesis and increased clearance may work synergistically to lower the circulating levels of natriuretic peptides.
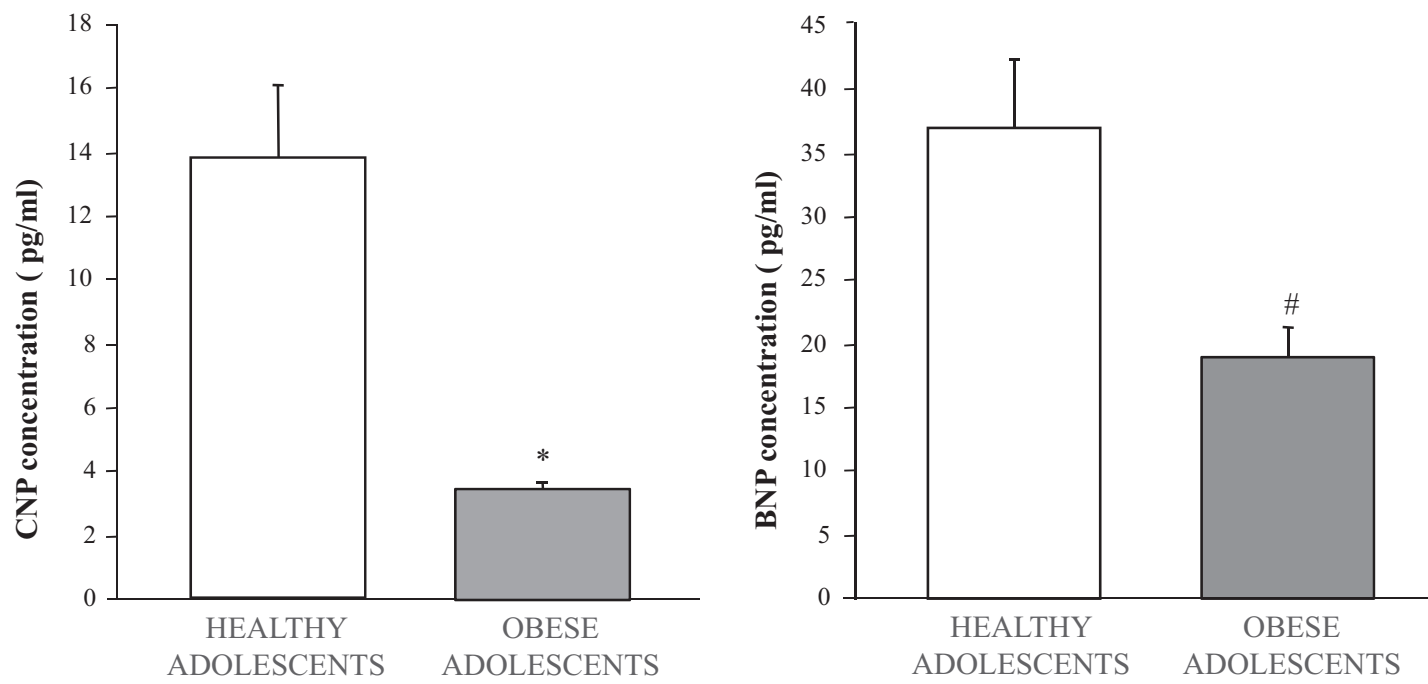

Fig. 1. CNP and BNP plasma levels in healthy and obese adolescent. White box: healthy subjects $(n=32)$, gray box: obese adolescents $(n=29) .{ }^{*} p<0.0001$, $\# p=0.003$. 
Alternatively, it has been hypothesized that the decreased levels of circulating natriuretic peptide are not the consequence of overweight/obesity, but rather a causative factor in the genotype or phenotype leading to development of obesity [21]. In fact, both ANP and BNP are now recognized factors involved in fat metabolism as stimulators of lipolysis in adipose tissue [19].

Data on plasma natriuretic peptide levels in obese children and adolescents are scarce, limited to pro-BNP and not univocal. To our knowledge there are only two studies in obese children/adolescents, showing contrasting results. One study reported higher levels of pro-BNP in obese vs normal-weight controls [41], while the other study did not find any difference between obese and non-obese subjects [42]. Both studies suggest that circulating pro-BNP in obese children/adolescents behaves differently than in obese adults, who have reduced levels of the peptide $[21,28,29,32,47]$. While our results agree with those found in obese adults, they do not agree with data reported in children/adolescents $[41,42]$. We do not have a clear-cut explanation for the different results in circulating BNP levels found among our own and others' studies. One possibility might be the different obese populations examined, which were younger than ours, spanning from about age 5 to 14 years [41] and from age 5 to 17 years [42], and the different assay method used. It is known that BNP and NT-proBNP results depend on the assay method used and on the age and gender of the population studied [4].

In recent years, the childhood obesity epidemic has begun to compromise the health of the pediatric population by promoting premature development of atherosclerosis and metabolic syndrome, both of which significantly increase the risk of cardiovascular disease early in life. Given the involvement of natriuretic peptides in these conditions $[17,25]$, it becomes extremely important to have age-specific reference intervals for this peptide, as reported in some recently published studies on natriuretic peptides $[4,16,27]$.

A limitation of this study is the lack of control subjects. However, we used our own reference data, specific for the BNP and CNP assay methods employed in this study. It is also interesting to note that both BNP and CNP had the same pattern in our overweight/obese subjects, supporting that an altered regulation of natriuretic peptides may be working at this age, as previously observed in adults. These data suggest that CNP determination, along with that of the other natriuretic peptides, may be considered a complementary tool for the characterization of these subjects. In this regard, the availability of drugs promoting the actions of natriuretic peptides may be an attractive therapeutic option for preventing cardiovascular disease.

\section{Funding}

This study was conducted within the context of the project entitled "Early diagnosis of organ metabolic and inflammatory damage related with cancer and cardio-metabolic risk in childhood obesity. Validation of panel-oriented biomarkers in obese animals and implementation in children and adolescents" (Unique Project Code B55E09000560002), supported by the Regione Toscana (Tuscany Region) under the Research Call "Innovation in Medicine 2009".

\section{References}

[1] Ahn SM, Yoo BS. Two problems with analyzing natriuretic peptide levels: obesity and acute myocardial infarction. Korean Circ J 2010;40:550-1.

[2] Bayes-Genis A, DeFilippi C, Jannuzzi JL. Understanding amino-terminal pro-Btype natriuretic peptide in obesity. Am J Cardiol 2008;101:89-94

[3] Cabiati M, Raucci S, Liistro T, Belcastro E, Prescimone T, Caselli C, et al. Impact of obesity on the expression pathway of C-type natriuretic peptide and its specific receptor, NPR-B, in a rat experimental model. PLoS ONE 2013;8:e72959.
[4] Cantinotti M, Clerico A, Murzi M, Vittorini S, Emdin M. Clinical relevance of measurement of brain natriuretic peptide and $\mathrm{N}$-terminal pro-brain natriuretic peptide in pediatric cardiology. Clin Chim Acta 2008;390:12-22.

[5] Cantinotti M, Storti S, Parri MS, Prontera C, Murzi B, Clerico A. Reference intervals for brain natriuretic peptide in healthy newborns and infants measured with automated immunoassay platform. Clin Chem Lab Med 2010;48: 697-700

[6] Cole TJ, Green PJ. Smoothing reference centile curves: the LMS method and penalized likelihood. Stat Med 1992;11:1305-19.

[7] Cole TJ, Bellizzi MC, Flegal KM, Diettz WH. Establishing a standard definition for child overweight and obesity worldwide: international survey. Br Med J 2000;320:1240-3

[8] Crandall DL, Ferraro GD, Cervoni P. Effect of experimental obesity and subsequent weight reduction upon circulating atrial natriuretic peptide. Proc Soc Exp Biol Med 1989;191:352-6.

[9] D’Annunzio G, Vanelli M, Pistorio A, Minuto N, Bergamino L, Lafusco D, Lorini R. Diabetes Study Group of the Italian Society for Pediatric Endocrinology and Diabetes Insulin resistance and secretion indexes in healthy Italian children and adolescents: a multicentre study. Acta Biomed 2009;80:21-8.

[10] Del Ry S, Maltinti M, Emdin M, Passino C, Catapano G, Giannessi D Radioimmunoassay for plasma C-type natriuretic peptide determination: methodological evaluation. Clin Chem Lab Med 2005;43:641-5.

[11] Del Ry S, Passino C, Maltinti M, Emdin M, Giannessi D. C-type natriuretic peptide plasma levels increase in patients with congestive heart failure as a function of clinical severity. Eur J Heart Failure 2005;7:1145-8.

[12] Del Ry S, Maltinti M, Piacenti M, Passino C, Emdin M, Giannessi D. Cardiac production of C-type natriuretic peptide in heart failure. J Cardiovasc Med 2006; 7:397-9.

[13] Del Ry S, Giannessi D, Maltinti M, Prontera C, Iervasi A, Colotti C, et al. Increased levels of C-type natriuretic peptide in patients with idiopathic left ventricular dysfunction. Peptides 2007;28:1068-73.

[14] Del Ry S, Maltinti M, Cabiati M, Emdin M, Giannessi D, Morales MA C-type natriuretic peptide and its relation to non invasive indices of left ventricular function in patients with chronic heart failure. Peptides 2008;29: $79-82$

[15] Del Ry S, Cabiati M, Stefano T, Catapano G, Caselli C, Prescimone T, et al. Comparison of NT-proCNP and CNP plasma levels in heart failure, diabetes and cirrhosis patients. Regul Peptides 2011;166:15-20.

[16] Del Ry S, Cantinotti M, Cabiati M, Caselli C, Storti S, Prescimone T, et al. Plasma C-type natriuretic peptide levels in healthy children. Peptides 2012;33:83-6.

[17] Del Ry S. C-type natriuretic peptide: a new cardiac mediator. Peptides 2012:40C:93-8.

[18] Dessì-Fulgheri P, Sarzani R, Tamburrini P, Moraca A, Espinosa E, Cola G, et al. Plasma atrial natriuretic peptide and natriuretic peptide receptor gene expression in adipose tissue of normotensive and hypertensive obese patients. Hypertens 1997; 15:1695-9.

[19] Engeli S, Sharma AM. The renin-angiotensin system and natriuretic peptides in obesity-associated hypertension. J Mol Med 2001;79:21-9.

[20] Gulberg V, Moller S, Henriksen JH, Gerbes AL. Increased renal production of C-type natriuretic peptide (CNP) in patients with cirrhosis and functional renal failure. Gut 2000;47:852-7.

[21] Horwich TB, Hamilton MA, Fonarow GC. B-type natriuretic peptide levels in obese patients with advanced heart failure. J Am Coll Cardiol 2006;47:85-90.

[22] Kalra PR, Clague JR, Bolger AP, Anker SD, Poole-Wilson PA, Struthers AD, et al. Myocardial production of C-type natriuretic peptide in chronic heart failure. Circulation 2003;107:571-3.

[23] Licata G, Volpe M, Scaglione R, Rubattu S. Salt-regulating hormones in young normotensive obese subjects Effects of saline load. Hypertension 1994;23:I20-4

[24] Maisel A, Mueller C. North America B-type natriuretic peptide (BNP) consensus working group. Congest Heart Fail 2008; $14: 4$

[25] Maisel AS, Choudhary R. Biomarkers in acute heart failure - state of the art. Nat Rev Cardiol 2012;9:478-90.

[26] Matthews DR, Hosker JP, Rudenski AS, Naylor BA, Treacher DF, Turner RC. Homeostasis model assessment: IR and beta-cell function from fasting plasma glucose and insulin concentrations in man. Diabetologia 1985;28:412-9.

[27] McCarthy HD, Cole TJ, Fry T, Jebb SA, Prentice AM. Body fat reference curves for children. Int J Obesity 2006;30:598-602.

[28] McCord J, Mundy BJ, Hudson MP, Maisel AS, Hollander JE, Abraham WT, et al. Relationship between obesity and B-type natriuretic peptide levels. Arch Intern Med 2004:164:2247-52.

[29] Mehra MR, Uber PA, Park MH, Scott RL, Ventura HO, Harris BC, et al. Obesity and suppressed B-type natriuretic peptide levels in heart failure. J Am Coll Cardio 2004:43:1590-5

[30] Meyer AA, Kundt G, Steiner M, Schuff-Werner P, Kienast W. Impaired flowmediated vasodilatation, carotid artery intima-media thickening and elevated endothelial plasma markers in obese children: the impact of cardiovascular risk factors. Pediatrics 2006:117:1560-7.

[31] Morabito D, Vallotton MB, Lang U. Obesity is associated with impaired ventricular protein kinase C-MAP kinase signaling and altered ANP mRNA expression in the heart of adult Zucker rats. J Investig Med 2001;49:310-8.

[32] Moro C, Smith SR. Natriuretic peptides: new players in energy homeostasis. Diabetes 2009;58:2726-8.

[33] Nathan BM, Moraan A. Metabolic complications of obesity in childhood and adolescence: more than just diabetes. Curr Opin Endocrinol Diabetes Obes $2008 ; 15: 21-9$ 
[34] Pilo A, Zucchelli GC, Malvano R, Masini S. Main features of computer algorithms for RIA data reduction Comparison of same different approaches for the interpolation of dose-response curve. J Nucl Med Allied Sci 1982;26:235-48.

[35] Prickett TCR, Yandle TG, Nicholls MG, Espiner EA, Richards AM. Identification of amino-terminal pro-C-type natriuretic peptide in human plasma. Biochem Biophys Res Commun 2001;286:513-7.

[36] Prickett TC, Kaaja RJ, Nicholls MG, Espiner EA, Richards AM, Yandle TG. Nterminal pro-C-type natriuretic peptide, but not C-type natriuretic peptide is greatly elevated in fetal circulation. Clin Sci (Lond) 2004;106:535-40.

[37] Prickett TCR, Lynn AM, Barrell GK, Darlow BA, Cameron VA, Espiner EA, et al. Amino-terminal proCNP: a putative marker of cartilage activity in postnatal growth. Pediatr Res 2005;58:334-40.

[38] Prickett TCR, Dixon B, Frampton C, Yandle TG, Richards AM, Espiner EA, et al. Plasma amino-terminal pro C-type natriuretic peptide in the neonate: relation to gestational age and postnatal linear growth. J Clin Endocrinol Metab 2008;93:225-32.

[39] Prontera C, Storti S, Emdin M, Passino C, Zyw L, Zucchelli GC, et al. Comparison of a fully automated immunoassay with a point-care testing method for B-type natriuretic peptide. Clin Chem 2005;51:1274-6.

[40] Rooney BBL. Predictors of obesity in childhood, adolescence, and adulthood in a birth cohort. Matern Child Health J 2011:15:1166-75.

[41] Saritas T, Tascilar E, Abaci A, Yozgat Y, Dogan M, Dundaroz R, et al. Importance of plasma $\mathrm{N}$-terminal pro B-type natriuretic peptide, epicardial adipose tissue, and carotid intima-media thicknesses in asymptomatic obese children. Pediatr Cardiol 2010;31:792-9.
[42] Siervo M, Ruggiero D, Sorice R, Nutile T, Aversano M, Iafusco M, et al. Body mass index is directly associated with biomarkers of angiogenesis and inflammation in children and adolescents. Nutrition 2012;28: 262-6.

[43] Skinner AC, Steiner MJ, Chung AE, Perrin EM. Cholesterol curves to identify population norms by age and sex in healthy weight children. Clin Pediatr 2012;51:233-7.

[44] Sokol RJ. The chronic disease of childhood obesity: the sleeping giant has awakened. J Pediatr 2000;136:711-3.

[45] The Fourth Report on the Diagnosis, Evaluation, and Treatment of High Blood Pressure in Children and Adolescents. National High Blood Pressure Education Program Working Group on High Blood Pressure in Children and Adolescents. Pediatrics 2004;114(2 Suppl. 4th Report):555-76.

[46] Vlachopoulos C, Ioakeimidis N, Printzios DT. Amino-terminal pro-C-type natriuretic peptide is associated with arterial stiffness, endothelial function and early atherosclerosis. Atherosclerosis 2010;211:649-55.

[47] Wang TJ, Larson MG, Levy D, Benjamin Leip EP, Wilson PW, et al. Impact of obesity on plasma natriuretic peptide levels. Circulation 2004;109: 594-600.

[48] Wiegand S, Dannemann A, Krude H, Gruters A. Impaired glucose tolerance and type 2 diabetes mellitus: a new field for pediatrics in Europe. Int J Obes 2005;29:S136-42

[49] Wright SP, Prickett TC, Doughty RN, Frampton C, Gamble GD, Yandle TG, et al. Amino-terminal pro-C-type natriuretic peptide in heart failure. Hypertension 2004;43:94-100. 